Article

\title{
Effects of Air Pollution on Human Health and Costs: Current Situation in São Paulo, Brazil
}

\author{
José Carlos Curvelo Santana ${ }^{1, *(\mathbb{D})}$, Amanda Carvalho Miranda ${ }^{2}(\mathbb{D}$, \\ Charles Lincoln Kenji Yamamura ${ }^{1}$, Silvério Catureba da Silva Filho ${ }^{2,3}$, Elias Basile Tambourgi ${ }^{3}$, \\ Linda Lee Ho ${ }^{1}\left(\mathbb{D}\right.$ and Fernando Tobal Berssaneti ${ }^{1, *}{ }^{(1)}$ \\ 1 Department of Production Engineering, University of São Paulo, Prof. Luciano Gualberto Avenue, 1380, \\ Butantã, São Paulo 05508-010, Brazil; charles.yamamura@usp.br (C.L.K.Y.); lindalee@usp.br (L.L.H.) \\ 2 Industrial Engineering Post Graduation Program, Nine July University, São Paulo 01525-000, Brazil; \\ mirandaca1@hotmail.com (A.C.M.); silveriocsf@yahoo.com.br (S.C.d.S.F.) \\ 3 School of Chemical Engineering, State University of Campinas, São Paulo 13083-970, Brazil; \\ eliastam@feq.unicamp.br \\ * Correspondence: jccurvelo@yahoo.com.br (J.C.C.S.); fernando.berssaneti@usp.br (F.T.B.)
}

Received: 22 April 2020; Accepted: 8 June 2020; Published: 15 June 2020

\begin{abstract}
This study focused on verifying whether the emission of air pollutants in São Paulo increases the costs and number of hospitalizations for respiratory diseases in Brazil. Data on pollutant emissions, hospitalizations, and hospital costs were collected from 2008 to 2017 and correlated with air quality standards. The results showed that the concentration of particulate matter increased each year during the study period and was highly correlated with hospitalizations due to respiratory diseases. Ozone $\left(\mathrm{O}_{3}\right)$ was within the quality standard throughout the study period but registered an increase in the mean and a positive correlation with hospitalizations due to respiratory diseases. The carbon monoxide $(\mathrm{CO})$, sulfur dioxide $\left(\mathrm{SO}_{2}\right)$, and nitrogen dioxide $\left(\mathrm{NO}_{2}\right)$ levels were within the quality standards throughout the study period with a decrease in the last years studied, but showed a positive correlation with hospitalizations due to respiratory diseases. The pollutant emissions and hospitalizations due to respiratory diseases had an inverse relationship with the monthly rainfall curve for São Paulo, which indicates that rainfall tended to reduce pollutant emissions and consequently hospitalizations due to inhalation of these pollutants. Because costs are directly associated with hospitalizations, both increased during the study period-302,000 hospitalizations at an average cost of 368 USD resulted in a total cost of 111 million USD. To reduce these costs, Brazil should implement stricter policies to improve the air quality of its major cities and develop a viable alternative to diesel vehicles.
\end{abstract}

Keywords: air quality index; pollutant emissions; human health; particulate material; pulmonary disease; environmental protection

\section{Introduction}

Growing urban development and new technologies, coupled with an increase in the global population, have resulted in high energy consumption, scarcity of natural non-renewable sources, and a general increase in pollutant emissions [1,2]. Air pollution is a mixture of particles, particulate matter (PM), and gases released into the atmosphere primarily by industries, motor vehicles, and thermal power plants, as well as from burning biomass and fossil fuels. Pollutants can be classified as primary or secondary: Primary pollutants are released directly into the atmosphere, while secondary pollutants result from chemical reactions between primary pollutants [3].

These and other factors affect the health mainly of children and the elderly and others that make up the risk group. About 500,000children, aged 0 to 10, are hospitalized for respiratory diseases in 
Brazil each year, which causes a cost to the public health system of US \$34 million [4]. In addition, the elderly adds an additional $60 \%$ to the total number of hospitalizations.

The number of hospitalizations registered by Brazilian Health System-Sistema Único de Saúde (SUS) has shown that the low air humidity in some months of the year combines with the vast pollution emission by regional fleets of diesel vehicles to directly affect hospitalization costs due to associated diseases [5].

As a consequence of the interactions, there was an increase in spending by the SUS for the treatment of patients with respiratory diseases. This causes Brazil to lose more than $5 \%$ of gross domestic product (GDP), which could be invested in the construction of new hospitals or in the purchase of new health equipment. According to Ravina et al. [6], the accounting of effects of air pollution on human health costs is a useful indicator to support decision-making and information at all management levels.

Thus, the aim of the present study was to verify if $\mathrm{PM}$, carbon monoxide (CO), sulfur dioxide $\left(\mathrm{SO}_{2}\right)$, nitrogen dioxide $\left(\mathrm{NO}_{2}\right)$, and ozone $\left(\mathrm{O}_{3}\right)$ emitted by several air sources in São Paulo contributed to the increased costs and number of hospitalizations for respiratory diseases for the period of 2008-2017. The data presented in this study correspond to all available values in the Brazilian government agencies, being reliable and representative of all the systems under study.

\section{Literature Review}

\subsection{Influence of Air Quality on Human Health}

The effects of air pollution on people have been the subject of research around the world to correlate the photochemical effects of air and health, the respiratory system, and the aggravation of allergic diseases. Gao et al. [7] reported that the world suffered economic losses of 129 billion USD in association with greenhouse gas (GHG) emissions in 2016. Researchers from different countries have been united in their quest to correlate the effects of air pollutants with respiratory diseases. In Switzerland, Kunzli et al. [8] identified an increase in the incidence of asthma in adults living in high-traffic regions. In the Netherlands, Gehring et al. [9] associated the rise in $\mathrm{PM}_{2.5}$ levels with an increased incidence of asthma in eight-year-old children. In Italy, De Marco et al. [10] reported that $\mathrm{PM}_{10}$ and $\mathrm{NO}_{2}$ emissions induced about 58,000 premature deaths/year due to cardiovascular and respiratory diseases. In Hong Kong, Ko et al. [11] associated the increased incidence of hospitalization of patients with chronic obstructive pulmonary disease (COPD) with environmental pollutants such as sulfur dioxide $\left(\mathrm{SO}_{2}\right), \mathrm{NO}_{2}, \mathrm{PM}_{2.5}$, and $\mathrm{PM}_{10}$. Andersen et al. [12] also found an increased incidence of COPD hospitalizations with increased $\mathrm{NO}_{2}$ emissions in cities in Denmark and Korea. Hu et al. [13] verified the incidence of individuals acquiring COPD with the increased emission of pollutants from biomass burning. In the USA, Reis et al. [14] noted a very high incidence of lung cancer in cities with $\mathrm{PM}_{2.5}$ concentrations of $28 \mathrm{ppb}$. They also noted a $31 \%$ increase in the lung cancer incidence when the $\mathrm{PM}_{2.5}$ concentration increased by $10 \mu \mathrm{g} / \mathrm{m}^{3}$. They noted that the situation could have been even worse; fortunately, new Environmental Protection Agency (EPA) standards were estimated to reduce PM emissions by 110,000 tons each year and toxic air pollutants such as benzene by 17,000 tons each year in the USA. Santos et al. [15] also showed that an elevation of $10 \mu \mathrm{g} / \mathrm{m}^{3}$ in the $\mathrm{PM}_{2.5}$ concentration is associated with an increment of $3.9 \mathrm{~mm} \mathrm{Hg}$ in the average systolic 24 -h blood pressure for hypertensive and/or diabetic workers. In China, Yu et al. [16] reported that air pollution causes more than 1 million premature deaths and 76 million disability-adjusted life years each year, and the corresponding disease burden has increased by $33 \%$ in the past 20 years. To account for the realistic spatial variability of air pollutants, Yu et al. [16] used remote sensing for observation. This has an advantage over in situ data in terms of determining the impact of air pollution on human health because it has better spatial coverage and thus provides better understanding of the spatial distribution of the human health impact. They used an aggregate risk index to account for the overall impact on human health of exposure to multiple air pollutants and to reflect the linear relationship between air pollution and health risks. 
Their results showed that Chinese areas with the highest risk due to air pollution are mainly located in the Taklimakan Desert, northern China, Sichuan Basin, and middle of Inner Mongolia. In the Americas, more than 131,000 people in low-income countries and 96,000 people in high-income countries are estimated to die each year due to air pollution-related diseases. The elderly, children, and patients with pre-existing chronic diseases are the groups most at risk [17].

In Brazil, an average of 22,000 people are estimated to lose their lives prematurely each year because of exposure to pollutants outside the home, especially in the urban environment. According to the World Health Organization (WHO), that could reach 36,000 people/year by 2040 [17]. In recent decades, studies on air pollution and its effects on human health in São Paulo have provided considerable evidence of an association between increased hospital admissions for illness in individuals exposed to atmospheric pollutants such as $\mathrm{O}_{3}, \mathrm{NO}_{2}, \mathrm{SO}_{2}, \mathrm{CO}$, and inhalable PM [18]. According to Bravo et al. [19], more than 99,000 deaths are attributed to air pollution every year. Miranda et al. [20] modelled pollutant emissions and found that almost 10,000 deaths/year are associated with $\mathrm{PM}_{2.5}$; the population segments most at risk are the elderly and children. The annual cost of immobility in São Paulo is equivalent to $7.5 \%$ of the city's GDP, which is a significant impact on residents' health [21]. Motor vehicles are mainly responsible for the high air pollution rates to which São Paulo people are exposed. Air pollution is estimated to reduce the average life expectancy in São Paulo by about 3.5 years [22].

Individuals most susceptible to diseases caused by pollutant emissions are children, the elderly, people with chronic diseases, and people with genetic susceptibility. In addition, pollutants can affect the human fetus during pregnancy by causing intrauterine growth retardation, prematurity, low birth weight, and —in the most severe cases—congenital anomalies and intrauterine or perinatal death [3].

The acute effects of air pollution on respiratory diseases mainly affect children and the elderly. Chronic exposure to $\mathrm{PM}_{2.5}$ emitted by fossil fuels, especially those containing lead, increases the risk of heart and respiratory disease and may even progress to lung cancer. Increased air pollution in large urban centers has also been associated with all risk factors for cardiovascular disease, such as cardiac arrhythmia, vasoconstriction and increased blood pressure, myocardial and cerebral ischemia, and the progression of arteriosclerosis [23]. According to Kunzli et al. [8], the main primary pollutants monitored by major environmental agencies in Brazil and the world are nitrogen oxides $\left(\mathrm{NO}_{2}\right.$ or $\mathrm{NOx}$ ), volatile organic compounds (VOCs), $\mathrm{CO}$, and $\mathrm{SO}_{2}$. An example of a secondary pollutant is $\mathrm{O}_{3}$, which is formed by the photo-induced oxidation of $\mathrm{VOCs}$ and $\mathrm{NO}_{2}$ in the presence of ultraviolet rays from sunlight.

The most studied pollutant is PM, which can be a primary or secondary pollutant. It varies in amount, size, shape, surface area, and chemical composition according to its production site and emission source. The deleterious effects of PM on human health depend on its size and chemical composition. The multiple chemical components of PM include an elemental or organic carbon core; inorganic compounds such as sulphates and nitrates; transition metal oxides; soluble salts; organic compounds such as polycyclic aromatic hydrocarbons; and biological materials such as pollen, bacteria, spores, and animal remain. PM is classified as follows according to the size of the total suspended particles: $\mathrm{PM}_{10}$ or the inhalable fraction comprises constituent particles up to $30 \mu \mathrm{m}$ in diameter; $\mathrm{PM}_{2.5}$ or fine PM comprises constituent particles less than $2.5 \mu \mathrm{m}$ in diameter; and $\mathrm{PM}_{0.1}$ or ultrafine PM comprises constituent particles less than $10 \mathrm{~nm}$ in diameter [8].

\subsection{Brazilian Panorama of Air Quality}

In Brazil, research in this field has developed in recent decades. Pinheiro et al. [24] analyzed the urban center of São Paulo for 10 years and found that an increase of $10 \mathrm{mg} / \mathrm{m}^{3}$ in the $\mathrm{PM}_{10}$ concentration increased the relative risk of death from airway diseases for the elderly. Gouveia et al. [25] studied the metropolitan region of São Paulo from 2000 to 2008 and correlated the number of hospital admissions for respiratory and cardiovascular diseases with $\mathrm{PM}_{10}$ exposure. For most of the region, pollution exposure only indicated an association with respiratory diseases. Only São Paulo and São Bernardo do Campo showed an association between the $\mathrm{PM}_{10}$ level and hospitalizations for cardiovascular diseases. 
Bernardes [26] reported that an increase in vehicle traffic density increased the hospitalization rate of children due to respiratory problems in São Paulo. In this study, the city was divided into 4000 cells, each with an area of approximately $2500 \mathrm{~m}^{2}$, to facilitate the identification of regions with the highest traffic. The analysis showed that a positive variation of one unit in traffic density caused a $1.3 \%$ increase in the rate of hospitalizations for respiratory problems in each group of 10,000 children.

São Paulo has a concentration of urban infrastructure and services in the area known as the expanded center, which has a high road density and traffic volume as well as the main access corridors. In São Paulo, there has been a decline in industrial pollution due to advances in filter technology and the current deindustrialization process. However, the steep increase in the vehicle fleet has kept pollution at health risk levels, even with newer models emitting less pollutants [26]. In the metropolitan region of São Paulo, there are 47,000 industries and about 100,000 commercial establishments. In the last decade, the population of the state capital grew $12 \%$, while the car fleet increased by $65 \%$ to reach 7 million in March 2017-that is, one vehicle for every 1.5 persons. This avalanche of cars on the streets causes daily traffic jams of more than $100 \mathrm{~km}$ during peak hours, which has intensified the emission of pollutants that aggravate respiratory diseases such as rhinitis, sinusitis, and pneumonia [27].

The composition of the gases emitted by each fuel is shown in Table 1, in addition, the percentages of fuels consumed in Brazil are also shown. As noted, diesel oil and gasoline are the fuels most consumed by the Brazilian vehicle fleet, in addition to being the main sources of emission of gaseous pollutants [28].

Table 1. Source of emissions from fuel consumed.

\begin{tabular}{ccccccc}
\hline \multirow{2}{*}{ Source } & \multicolumn{5}{c}{ Gaseous Emissions (\%) } & \multirow{2}{*}{ Consumption (\%) } \\
\cline { 2 - 6 } & $\mathbf{C O}$ & VOC & NOx & $\mathbf{S O}_{\mathbf{2}}$ & $\mathbf{M P}$ & \\
\hline Gasoline & 27.7 & 2.7 & 1.2 & 0.22 & 0.21 & 32.7 \\
Ethanol & 16.7 & 1.9 & 1.2 & 0 & 0 & 10.1 \\
Diesel oil & 17.8 & 2.9 & 13 & 2.72 & 0.81 & 40.5 \\
Natural gas & 6.0 & 0.7 & 1.1 & 0 & 0 & 9.9 \\
\hline \multicolumn{7}{c}{ Source: National Petroleum Agency of Brazil, ANP [28]. }
\end{tabular}

De Oliveira et al. [29] and Vilas Boas et al. [30] evaluated the genotoxic effects of air pollution $\left(\mathrm{PM}_{2.5}\right.$ and $\left.\mathrm{NO}_{2}\right)$ on São Paulo city workers and found that workers in the most urban areas were exposed to higher concentrations of $\mathrm{PM}_{2.5}$ and showed higher micronucleus frequencies for both buccal mucosa and lymphocytes. Saldiva et al. [31] verified the influence of exposure of pregnant women to polluted city air and found that PM produced by traffic emissions and photochemical pollutants involved in the photochemical cycle $\left(\mathrm{O}_{3}\right.$ and $\left.\mathrm{NO}_{2}\right)$ also exhibited significant and robust risks for premature births. Missagia et al. [32] have reported evidence that problems caused by air pollution are spreading to medium-sized Brazilian cities. They evaluated the air pollution effects on the lung functions of 117 children and adolescents by measuring the peak expiratory flow (PEF) from 2008 to 2009 in an area exposed to industrial emissions in Anchieta and Guarapari cities in the state of Espírito Santo. Their results show a significant negative association between the PM concentration and PEF rate in this population, and the results remained significant even after being adjusted for temperature, humidity, body mass index, coughing, wheezing, and coryza. The observed adverse effects suggested an association between an increase in $\mathrm{PM}_{10}$ and reduced lung function. In addition, children and people from risk groups have also been reported to be suffering from respiratory diseases in other medium-sized Brazilian cities such as São José do Rio Preto and Volta Redonda [33-35].

\section{Materials and Methods}

Data on the number of hospitalizations for respiratory diseases and their respective costs in hospital units for São Paulo were collected from the TABNET-SUS online platform with the following filters: SUS hospital morbidity, city selection, and time range. Thus, data could be collected on the number of 
hospitalizations and amount spent by the Brazilian government in public or private hospitals each month from 2008 until 2017. The costs and number of monthly hospitalizations that occurred due to respiratory diseases in São Paulo hospitals were quantified and correlated with pollutant emissions in the region during this period. The São Paulo State Environmental Company (CETESB) is a government agency responsible for the control, supervision, monitoring, and licensing of pollution-generating activities in this area with the fundamental concern of preserving and restoring the water quality, air, and soil [36]. CETESB has several sensors distributed in various parts of São Paulo that continuously monitor the air quality and send it to its central line [36]. The air pollutants emitted monthly with the most impact on the population's health were monitored according to the relationship presented by Arbex et al. [3] and Marchin and Nascimento [4], as cited by WHO [17]. Research was conducted on the CETESB website, under the link Qualar (air quality) (http://ar.cetesb.sp.gov.br/padroes-de-quality-do-ar/) [36], and the monthly pollutant emissions were filtered according to the metropolitan region (Alto Tietê). The following pollutants were collected for the neighborhoods of São Paulo from 2008 to 2017: $\mathrm{PM}_{2.5}$, $\mathrm{PM}_{10}, \mathrm{O}_{3}, \mathrm{NO}_{2}, \mathrm{SO}_{2}$, and $\mathrm{CO}$. Not all pollutants started being effectively controlled in 2008, but full monitoring took place from 2010 onwards. Thus, the pollutant emission ratio was collected for this period. CETESB used beta radiation to determine $\mathrm{PM}_{2.5}$ and $\mathrm{PM}_{10}$, pulse fluorescence to determine $\mathrm{SO}_{2}$, chemiluminescence to determine $\mathrm{NO}_{x}$, non-expendable infrared to determine $\mathrm{CO}$, and the ultraviolet method to determine $\mathrm{O}_{3}[36]$.

The rainfall index was another factor considered because rainfall disperses gases and improves air quality. To determine the mean rainfall index in São Paulo, the climatological average (rainfall behavior and temperature fluctuations) was investigated from a series of available data observed over the last 30 years from the Climatologia website (http://www.climatempo.com.br/climatologia/558/saopaulo-sp) [4].

Monthly emissions were compared to the national standard set by the National Council of the Environment (CONAMA) in 28 June 2009 and international standard established by WHO [17], as given in Table 2. The CETESB website had no gaseous emission data available to the population before 2010, so the time period could not be 10 years [36].

Table 2. National Council of the Environment (CONAMA) and World Health Organization (WHO) laws on pollutant exposure standards.

\begin{tabular}{ccccccc}
\hline Law & MP $_{\mathbf{2 . 5}}$ & $\mathbf{M P}_{\mathbf{1 0}}$ & $\mathbf{S O}_{\mathbf{2}}$ & NO $_{\mathbf{2}}$ & $\mathbf{O}_{\mathbf{3}}$ & CO \\
\hline CONAMA */São Paulo & $60 \mu \mathrm{g}(24 \mathrm{~h})$ & $120 \mu \mathrm{g}(24 \mathrm{~h})$ & $60 \mu \mathrm{g}(24 \mathrm{~h})$ & $260 \mu \mathrm{g}(24 \mathrm{~h})$ & $140 \mu \mathrm{g}(8 \mathrm{~h})$ & $9 \mu \mathrm{g}(8 \mathrm{~h})$ \\
\hline WHO $^{*}$ & $25 \mu \mathrm{g}(24 \mathrm{~h})$ & $50 \mu \mathrm{g}(24 \mathrm{~h})$ & $20 \mu \mathrm{g}(24 \mathrm{~h})$ & $200 \mu \mathrm{g}(24 \mathrm{~h})$ & $100 \mu \mathrm{g}(8 \mathrm{~h})$ & $10 \mu \mathrm{g}(8 \mathrm{~h})$ \\
\hline
\end{tabular}

* Standard for short exposure time. Source: CONAMA-SP [36] and WHO [17].

The tolerable level of exposure to pollutants according to WHO is quite restrictive compared to that recommended by CONAMA. For São Paulo, the limits needed to be extrapolated in order to ensure greater rigor in the emission control and exposure control ranges mentioned above, which differed from the standards adopted by other state capitals based on the national standard.

Because the pollutant emissions were surveyed on CETESB's Qualar website, the exposure limits recommended by this official body were also used as a reference. Table 3 classifies the air quality and relates possible health problems to exposure to polluted air according to CETESB [36]. The air quality index $\left(I_{A Q}\right)$ was calculated for each considered parameter with Equation (1). The air quality was considered to have the highest value for the quality index among the evaluated parameters.

$$
I_{A Q}=N_{b}+\left(C-C_{b}\right) \cdot\left(\frac{N_{t}-N_{b}}{C_{t}-C_{b}}\right)
$$

Here, $C$ is the measured concentration and $C_{b}$ and $C_{t}$ are the concentrations corresponding to the bottom and top values, respectively, of the concentration range. $N_{b}$ and $N_{t}$ are the quality index values corresponding to the bottom and top values, respectively, of the concentration range. 
Table 3. Level classification of air quality according CONAMA-SP.

\begin{tabular}{|c|c|c|c|c|c|c|c|}
\hline $\begin{array}{l}\text { Air Quality } \\
\text { Levels }\end{array}$ & $\mathrm{MP}_{10}\left(\mu \mathrm{g} / \mathrm{m}^{3}\right) 24 \mathrm{~h}$ & $\mathrm{MP}_{2.5}\left(\mu \mathrm{g} / \mathrm{m}^{3}\right) 24 \mathrm{~h}$ & $\mathrm{O}_{3}\left(\mu \mathrm{g} / \mathrm{m}^{3}\right) 8 \mathrm{~h}$ & $\mathrm{CO}(\mathrm{ppm}) 8 \mathrm{~h}$ & $\mathrm{NO}_{2}\left(\mu \mathrm{g} / \mathrm{m}^{3}\right) 1 \mathrm{~h}$ & $\mathrm{SO}_{2}\left(\mu \mathrm{g} / \mathrm{m}^{3}\right) 24 \mathrm{~h}$ & $\begin{array}{c}\text { Consequences to Human } \\
\text { Health }\end{array}$ \\
\hline Good (0-40) & $0-50$ & $0-25$ & $0-100$ & $0-9$ & $0-200$ & $0-25$ & \\
\hline $\begin{array}{l}\text { Moderate } \\
(43-80)\end{array}$ & $>50-100$ & $>25-50$ & $>100-130$ & $>9-11$ & $>200-240$ & $>20-40$ & $\begin{array}{l}\text { Affect only people in most } \\
\text { susceptible group *. These } \\
\text { will exhibit symptoms such } \\
\text { as dry cough and tiredness. }\end{array}$ \\
\hline Bad (81-120) & $>100-150$ & $>50-75$ & $>130-160$ & $>11-13$ & $>240-320$ & $>40-365$ & $\begin{array}{c}\text { Everyone can have } \\
\text { symptoms such as dry } \\
\text { cough, tiredness, and } \\
\text { burning eyes, nose, and } \\
\text { throat. People in most } \\
\text { susceptible group may have } \\
\text { more serious health effects. }\end{array}$ \\
\hline Poor (121-200) & $>150-250$ & $>75-125$ & $>160-200$ & $>13-15$ & $>320-1130$ & $>365-800$ & $\begin{array}{l}\text { All people will have } \\
\text { worsening of the previously } \\
\text { mentioned symptoms and } \\
\text { breathlessness and } \\
\text { wheezing. People in the } \\
\text { sensitive group can have } \\
\text { serious health effects. }\end{array}$ \\
\hline Very poor $(>200)$ & $>250$ & $>125$ & $>200$ & $>15$ & $>1130$ & $>800$ & $\begin{array}{l}\text { Everyone may be at serious } \\
\text { risk of manifestations of } \\
\text { respiratory and } \\
\text { cardiovascular disease. } \\
\text { Increase in premature } \\
\text { deaths in people of most } \\
\text { susceptible group, }\end{array}$ \\
\hline
\end{tabular}


Statistical analysis of the data was performed with Pearson's correlation coefficient; the direction of this correlation (whether positive or negative) between two metric scale variables (interval or ratio) was evaluated [37-41]. The variables of choice were the individual emissions of each pollutant and the number of hospitalization cases for respiratory diseases. The results were interpreted according to the correlations obtained between the variables as follows:

- $\quad 0.7-1.0$ indicates a strong correlation;

- $\quad 0.5-0.7$ indicates a moderate correlation;

- $\quad 0.3-0.5$ indicates a weak correlation; and

- $0-0.3$ indicates a negligible correlation.

Because the coefficient was determined from the linear fit, the formula contains no fit information, i.e., it is composed only of the data $[37,40,42]$. The following proposition was verified: the $\mathrm{PM}_{2.5}, \mathrm{PM}_{10}$, $\mathrm{O}_{3}, \mathrm{NO}_{2}, \mathrm{SO}_{2}$, and $\mathrm{CO}$ emitted by several air sources in São Paulo contribute to the increased costs and number of hospitalizations for respiratory diseases. The pollutants were checked for whether all or only some contributed to the increase in costs and hospitalizations.

Rain is known to decrease air pollution, so the rainfall was also checked for whether it was correlated with a reduction in costs and the number of hospitalizations for respiratory diseases. If an inverse relationship with the rain could be confirmed, then the influence of $\mathrm{PM}_{2.5}, \mathrm{PM}_{10}, \mathrm{O}_{3}, \mathrm{NO}_{2}, \mathrm{SO}_{2}$, and $\mathrm{CO}$ should increase in its absence. A partial index correlation was used for verification; only the period without rain was used to verify its effect.

\section{Results and Discussion}

Table 4 presents the number of total monthly hospitalizations for respiratory diseases from 2008 to 2017. The monthly average number of hospitalizations for respiratory diseases was approximately 2518 people/month, while the annual average was above 30,215 hospitalizations/year. Hospitalizations were concentrated between April and September, which are less rainy months in São Paulo. Table 5 presents the costs of these hospitalizations. The average monthly cost was around 927,000 USD/month, and the annual average was 11.12 million USD/year. In 2013 and 2014, the highest expenses for hospitalizations were observed at 51 million USD in each year. Between 2008 and 2017, more than 302,000 hospitalizations due to pollutant exposure were observed in São Paulo at a total cost of over 111 million USD for the Brazilian health system [5], which is equivalent to an average cost of 368.18 USD/hospitalization. According to WHO [17], improving the air quality by replacing fossil fuels with renewable fuels such as biodiesel could reduce pollutant emissions by $30 \%$, which would have resulted in a total savings for SUS of 33.3 million USD during this period. This value could be invested in urban mobility measures (e.g., bicycle paths, railway lines, and subways) to relieve the use of cars in the expanded center and reduce pollutant emissions.

Similar studies have indicated that air pollution cost the SUS [5] more than 2 million USD from 1993 to 1995 . The money was spent to treat patients who developed diseases directly related to excess pollutants. This amount of money could be used to perform 784,000 medical consultations or 10,100 normal births in SUS-affiliated hospitals [43].

In the city of São José do Rio Preto in São Paulo state, Mantovani et al. [33] reported excess hospitalizations for respiratory diseases due to pollutants was on the order of 650 cases in 3 years, which represents an increase in spending of around 50,000 USD for the SUS. In the city of Volta Redonda in Rio de Janeiro state, Paiva [35] estimated the annual spending on hospitalizations due to pollutant exposure from 2005 to 2007 to be 44,000 USD. Thus, the negative impact of pollutant emissions on the population's quality of life was observed along with the economic setback to the public health system, which could have used these costs to invest in improving infrastructure to better serve the population. 
Table 4. Data on hospitalizations for respiratory diseases in São Paulo from 2008 to 2017.

\begin{tabular}{|c|c|c|c|c|c|c|c|c|c|c|}
\hline \multicolumn{11}{|c|}{ Monthly Hospitalizations } \\
\hline $\begin{array}{c}\text { Year } \\
\text { Month }\end{array}$ & 2008 & 2009 & 2010 & 2011 & 2012 & 2013 & 2014 & 2015 & 2016 & 2017 \\
\hline 1 & 1513 & 1648 & 2176 & 2150 & 1556 & 1968 & 2080 & 1739 & 1669 & 1749 \\
\hline 2 & 1056 & 1556 & 1832 & 2122 & 1715 & 1719 & 1631 & 1577 & 1464 & 1508 \\
\hline 3 & 1646 & 2396 & 2831 & 3026 & 2368 & 2218 & 2304 & 2250 & 2361 & 2715 \\
\hline 4 & 2072 & 2839 & 3289 & 3326 & 3085 & 3445 & 2951 & 3120 & 3483 & 2728 \\
\hline 5 & 3056 & 3004 & 2997 & 2960 & 3038 & 3395 & 3358 & 3015 & 3297 & 2871 \\
\hline 6 & 2955 & 2946 & 3114 & 2407 & 3065 & 2836 & 2972 & 2730 & 3015 & 2812 \\
\hline 7 & 3177 & 3185 & 2781 & 2967 & 2973 & 3159 & 2605 & 2920 & 3101 & 2561 \\
\hline 8 & 2832 & 3257 & 2779 & 2464 & 2792 & 2915 & 2476 & 2480 & 2950 & 2523 \\
\hline 9 & 3065 & 3351 & 2831 & 2654 & 2565 & 2590 & 2554 & 2226 & 2606 & 2191 \\
\hline 10 & 2716 & 3021 & 2842 & 2551 & 2252 & 2527 & 2567 & 2133 & 2408 & 2302 \\
\hline 11 & 2047 & 2665 & 2907 & 2556 & 2286 & 2474 & 2413 & 1957 & 2295 & 2286 \\
\hline 12 & 2078 & 2172 & 2723 & 2192 & 1841 & 1959 & 1896 & 1796 & 2251 & 1778 \\
\hline Subtotal & 28,213 & 32,040 & 33,102 & 31,375 & 29,536 & 31,205 & 29,807 & 27,943 & 30,900 & 28,024 \\
\hline Average & 2351 & 2670 & 2759 & 2615 & 2461 & 2600 & 2484 & 2329 & 2575 & 2335 \\
\hline \multicolumn{8}{|c|}{ Total hospitalizations in the period } & \multicolumn{2}{|c|}{302,145} & \\
\hline
\end{tabular}

Source: DATA/SUS [5].

Table 5. Data on hospitalization costs for respiratory diseases in São Paulo from 2008 to 2017.

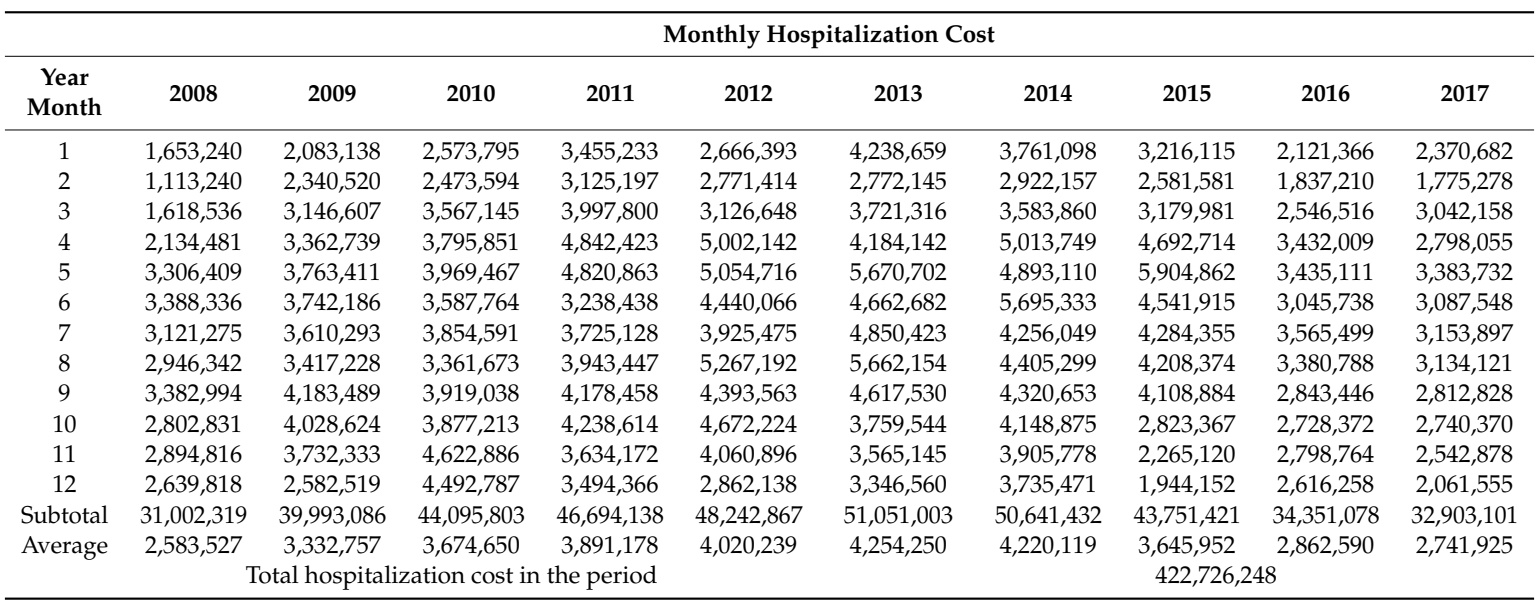

Source: DATA/SUS [5].

\subsection{Effects of Particulate Matter Emissions}

Figure 1 shows the behavior of the (a) $\mathrm{PM}_{10}$ and (b) $\mathrm{PM}_{2.5}$ emissions from 2010 to 2017. The concentrations $\left(\mu \mathrm{g} / \mathrm{m}^{3}\right)$ per day were compared to the WHO and CONAMA-SP standards to determine whether they exceeded the recommended exposure limits $[17,36]$. The $\mathrm{PM}_{2.5}$ values were collected from 2011, so no 2010 data were available. Both curves clearly show increased emissions between June and September, which coincides with the periods of no rain. The PM concentrations doubled from the initial values between July and August. Throughout the study period, the PM concentrations were above the recommended WHO standard [17]. In June and August, the PM concentrations exceeded the Brazilian standard, which is less strict than the WHO standard. These high PM concentrations were due to the burning of fossil fuels and dust from roads and construction. They can cause airway irritation, induce oxidative stress in the lungs and bronchial tubes, and consequently lead to systemic inflammation. They can also cause bronchial remodeling, COPD, and even cancer after chronic exposure $[3,18]$. The PM concentrations were considered extreme and major contributors to the poor respiratory health of the population. Arbex et al. [3] proved that $\mathrm{PM}_{2.5}$ can reach the pulmonary alveoli, pass through the bloodstream, and cause COPD. The data for 
$\mathrm{PM}_{2.5}$ are alarming and call attention to the lack of rigor regarding compliance to current legislation. The data confirm the difficulty for the government to establish effective public policies for emission control. Sustainable and urban mobility solutions are needed for São Paulo.

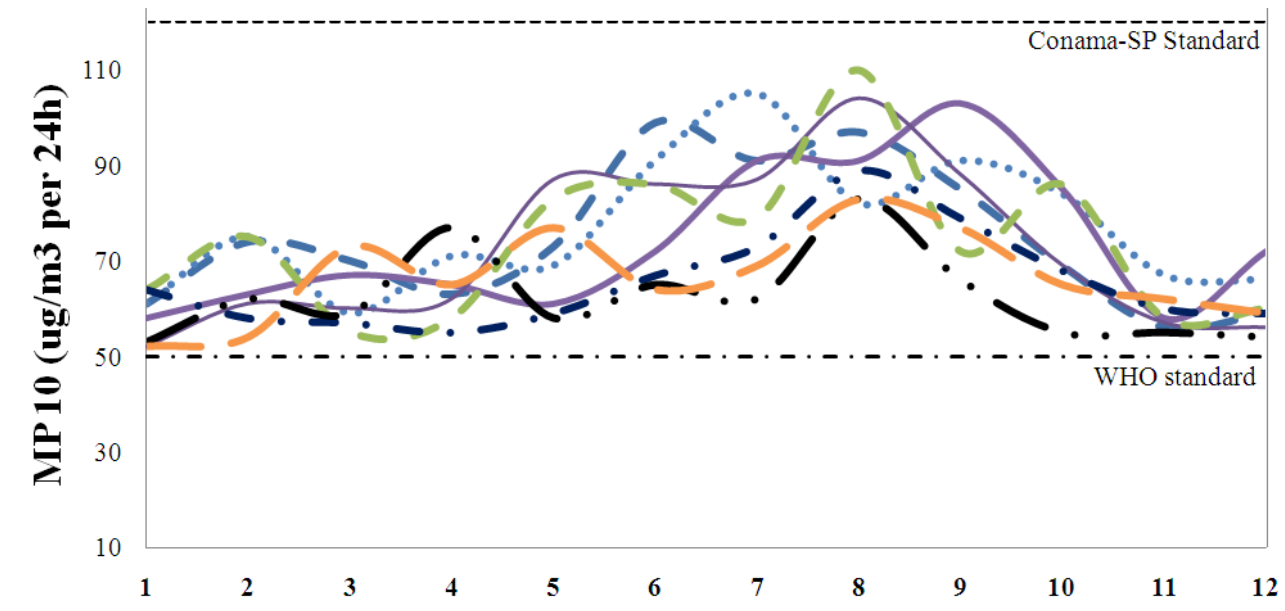

Time (month)
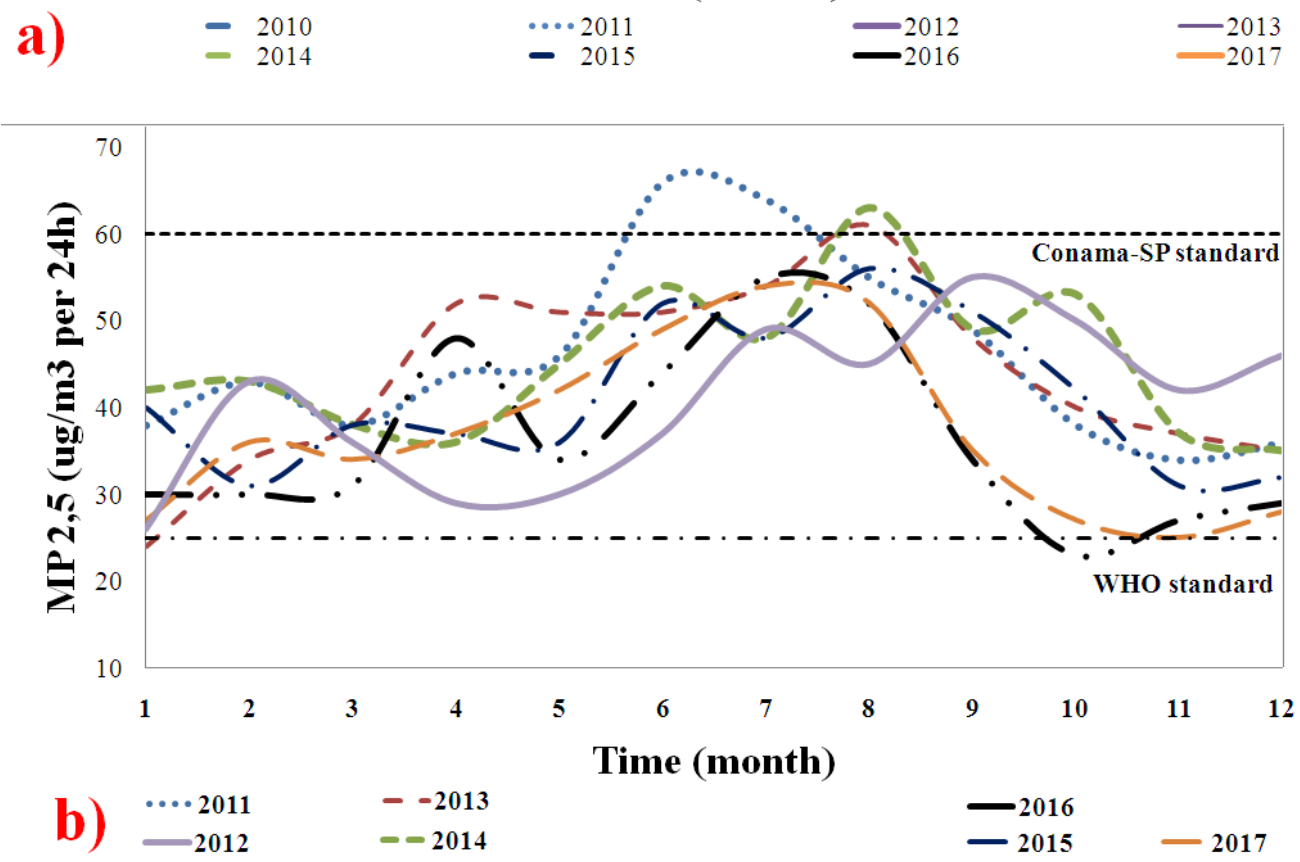

Figure 1. Variation of gaseous pollutant emissions in the city of São Paulo between 2010 and 2017. (a) $\mathrm{PM}_{10}$ and (b) $\mathrm{PM}_{2.5}$ emissions.

Missagia et al. [32] conducted a similar study in the city of Vitória-ES, monitoring exposure to $\mathrm{PM}_{2.5}$ emissions for 39 days. They observed that the emissions exceeded the range recommended by WHO for five days of this period and an increase in hospitalization cases for asthma, bronchitis, rhinitis, and seizures of coughs and sneezing. In the city of Rio Branco-Acre, Mascarenhas [44] found that the $\mathrm{PM}_{2.5}$ concentration significantly increased during the forest biomass burning period, which increases asthma cases for hospitals in the region in children under 10 years old.

Ghering et al. [9] followed the first eight years of life of 3863 children in communities in the north, west, and central Netherlands. High $\mathrm{PM}_{2.5}$ levels were associated with increases of $28 \%, 29 \%$, and $15 \%$, respectively, in the above regions in the incidence and prevalence of asthma symptoms. Similarly, Pandya et al. [45] reported increased cases of bronchial asthma and allergic respiratory diseases due to excessive exposure to $\mathrm{PM}_{10}$ from burning fuels, especially diesel. 
Recently, Santos et al. [39] observed an association between continuous $\mathrm{PM}_{2.5}$ exposure and increased blood pressure in hypertensive outdoor workers. Similar results were obtained for pregnant women in China [41]. The association between $\mathrm{PM}_{2.5}$ and the mortality of people in risk groups has been proven by Erickson et al. [38] in Canada and Polezer et al. [46] in Brazil, which demonstrates that this pollutant is one of the most aggressive against humans.

\subsection{Effects of Carbon Monoxide (CO) and Nitrogen Dioxide $\left(\mathrm{NO}_{2}\right)$ Emissions}

Figure 2 shows the behavior of (a) $\mathrm{CO}$ and (b) $\mathrm{NO}_{2}$ emissions from 2010 to 2017. The concentrations $\left(\mu \mathrm{g} / \mathrm{m}^{3}\right)$ per day were compared with the limits set by the WHO and CONAMA-SP standards. The CO and $\mathrm{NO}_{2}$ emissions were within the limits of both standards (WHO and CONAMA-SP); this indicates that their harmful effects on the respiratory health of the São Paulo population were neutral or low $[17,36]$.
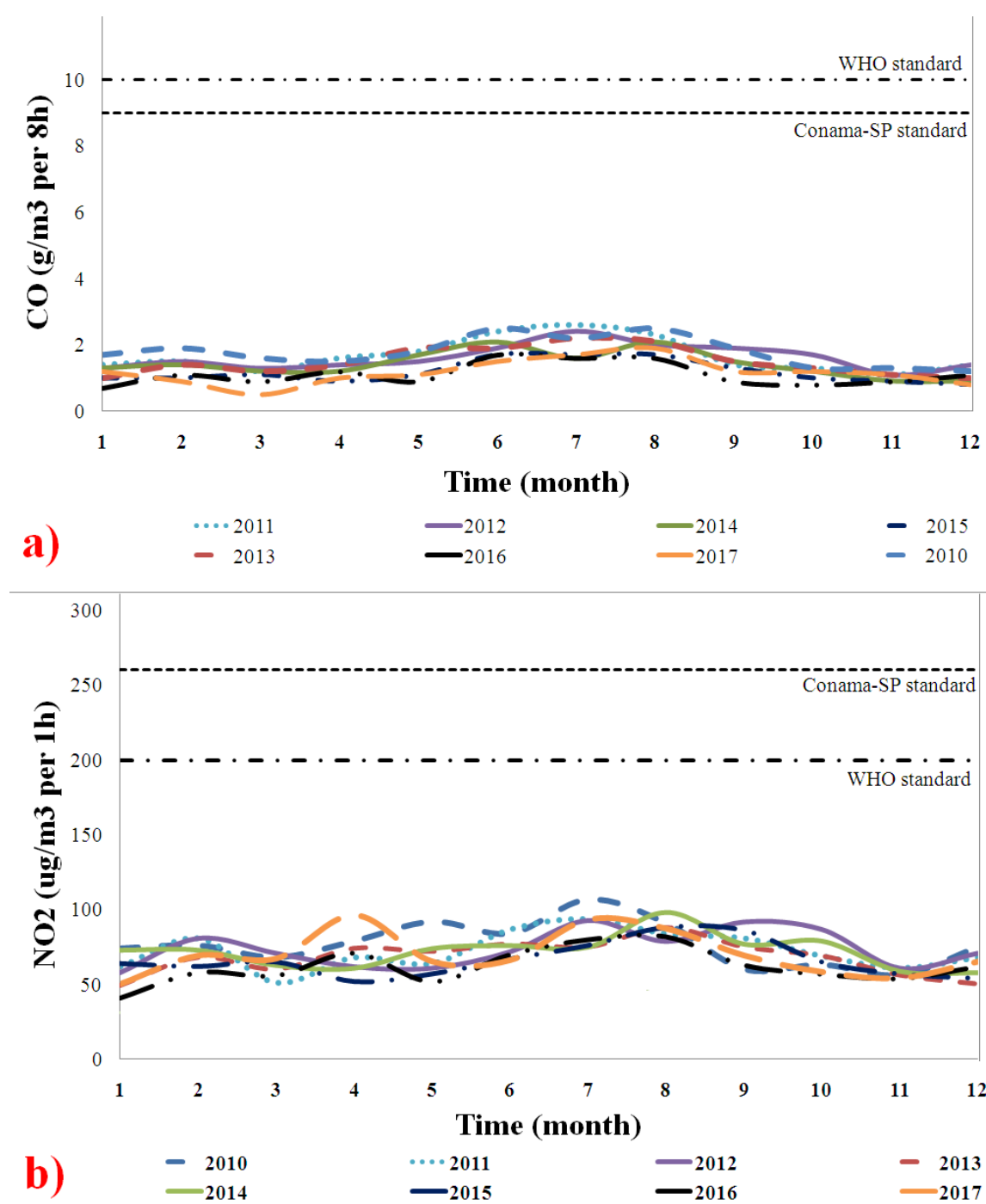

Figure 2. Variation of gaseous pollutant emissions in the city of São Paulo between 2010 and 2017.

(a) Carbon monoxide $(\mathrm{CO})$ and $(\mathbf{b})$ nitrogen dioxide $\left(\mathrm{NO}_{2}\right)$ emissions.

According to Arbex et al. [3], excessive exposure to CO can cause vomiting, nausea, and dizziness; new-born children are the patients most susceptible to these diseases. In São Paulo, Pacheco [47] found an association between CO and upper airway infections. Barbosa et al. [48] analyzed the association between pollution and pediatric emergency care for sickle cell disease patients and found that $\mathrm{CO}$ and $\mathrm{O}_{3}$ were associated with increases in total care of $16.5 \%$ and $9.8 \%$, respectively. However, the Brazilian 
Institute of Geography and Statistics (IBGE) reported that the infant mortality rate in São Paulo fell from 11.91 deaths per 10,000 births in 2010 to 10.91 deaths in 2017 [49]. This is evidence that controlling these emissions may minimize their effects on the death of children.

Arbex et al. [3] explained that $\mathrm{NO}_{2}$ has irritating potential and affects the mucosa of the nose and throat, which causes coughing and allergies. Negrisoli and Nascimento [50] investigated the prevalence of allergic respiratory diseases in children and considered different urban regions and the flow of vehicles. Their results indicated that areas with intense vehicular traffic have a prevalence of asthma, rhinitis, and other symptoms associated with $\mathrm{NO}_{2}$ emissions. Vieira et al. [51] observed that $\mathrm{NO}_{2}$ caused symptoms typically associated with respiratory diseases in children from the urban area of São Paulo. The entire population exhibited wheezing, which is characteristic of asthma, at some stage of the study.

In the present study, even though the observed emissions were not at significant levels according to national and international standards, the importance of monitoring them and applying corrective actions to minimise exposure was emphasised.

\subsection{Effects of Sulfur Dioxide $\left(\mathrm{SO}_{2}\right)$ and Ozone $\left(\mathrm{O}_{3}\right)$ Emissions}

Figure 3 shows the behavior of (a) $\mathrm{SO}_{2}$ and (b) $\mathrm{O}_{3}$ emissions from 2010 to 2017. The concentrations $\left(\mu \mathrm{g} / \mathrm{m}^{3}\right)$ per day were compared to the WHO and CONAMA-SP standards. The $\mathrm{SO}_{2}$ emissions were below the WHO and CONAMA-SP standards throughout the study period.
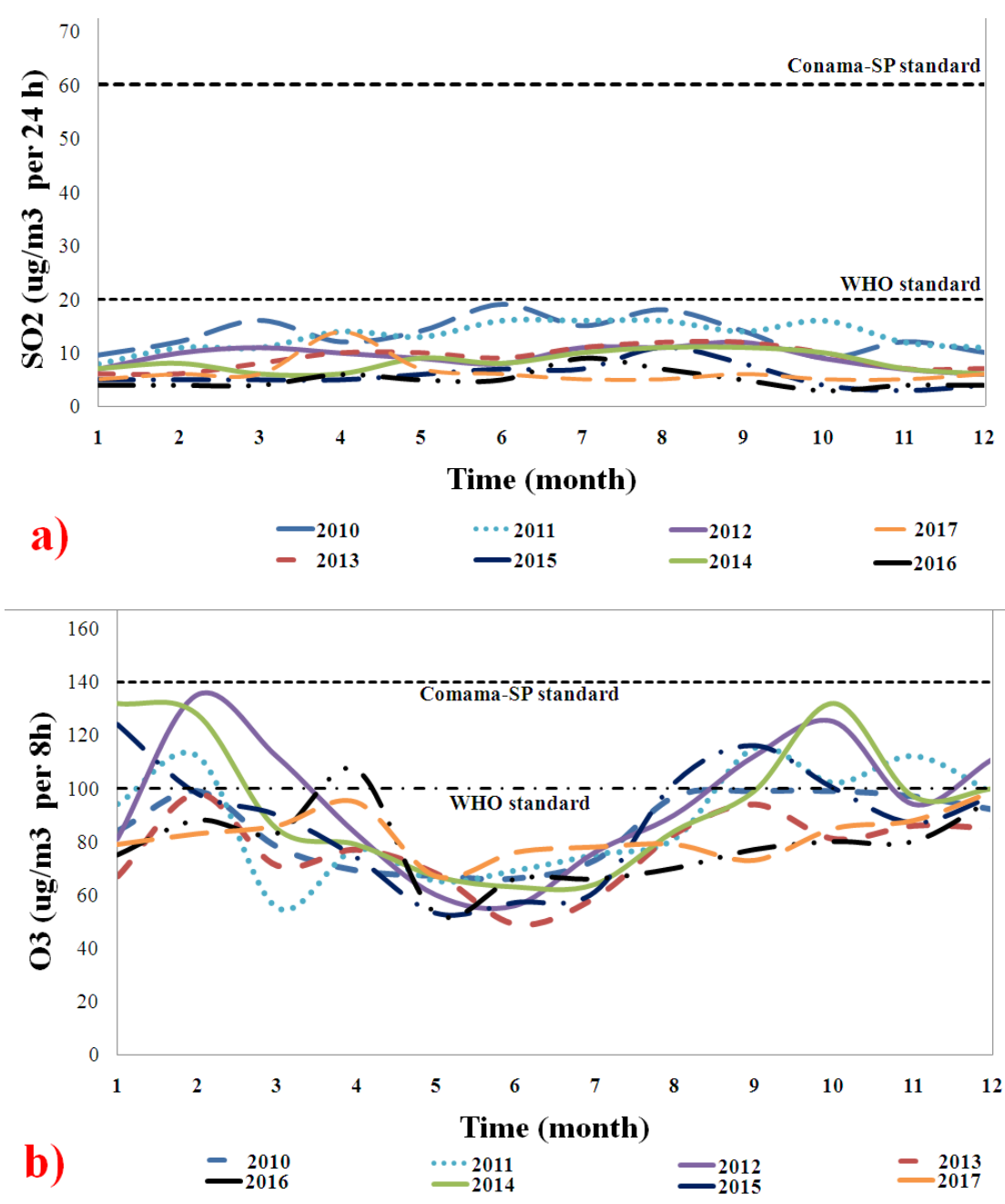

Figure 3. Variation of gaseous pollutant emissions in the city of São Paulo between 2010 and 2017.

(a) Sulfur dioxide $\left(\mathrm{SO}_{2}\right)$ and $(\mathbf{b})$ ozone $\left(\mathrm{O}_{3}\right)$ emissions. 
Arbex et al. [3] demonstrated that $\mathrm{SO}_{2}$ may compromise the thyroid, bronchi, and bronchioles, which can cause an allergic reaction and bronchoconstriction. Santos et al. [15] associated maternal exposure to $\mathrm{SO}_{2}$ with a low birth weight. Xiaolin et al. [52] indicated that short periods of exposure to $\mathrm{SO}_{2}$ can cause changes in lung function and respiratory symptoms. In this study, however, the $\mathrm{SO}_{2}$ levels were in accordance with the norms, so we cannot make these associations reported in the literature.

Figure $3 \mathrm{~b}$ shows that $\mathrm{O}_{3}$ emissions were above the WHO standards in November and February (i.e., rainiest period in São Paulo) for 2010 to 2014. The formation of $\mathrm{O}_{3}$ is due to the chemical reaction between primary pollutants such as CO, NOx, and hydrocarbons and sunlight [53]. In São Paulo, the first months of the year are summer; even though it is rainy, the solar incidence and lightning storms are corroborated with the intensification of chemical reactions that produce ozone. The same happens at the end of the year with spring, which is not rainy but has high temperature and solar intensity.

According to Arbex et al. [3], $\mathrm{O}_{3}$ induces respiratory inflammation, airway obstruction, coughing, and discomfort. Nardocci [54] associated the air pollution from the intense traffic with increased respiratory and cardiovascular problems, particularly in the elderly and children, due to $\mathrm{O}_{3}$. In the city of Cubatão, Jasinski et al. [55] evaluated the effects of pollution on respiratory morbidity in children and adolescents. Their results showed that chronic effects due to $\mathrm{O}_{3}$ were observed in children from 0 to 10 years old, while the effects of acute exposure to $\mathrm{O}_{3}$ was observed in adolescents.

In general, emissions have been observed to be directly related to aggravated cases of respiratory diseases in cities with heavy vehicle traffic, such as São Paulo. The most influential pollutants in this study were $\mathrm{PM}_{10}, \mathrm{PM}_{2.5}$, and $\mathrm{O}_{3}$, which exceeded the limits set by the CONAMA and WHO standards and are potentially harmful to the respiratory health of the population.

\subsection{Rainfall Effect}

Figure 4 shows the monthly changes in the total emissions, costs, number of hospitalizations, and rainfall. The data comprised the sum of all emission parameters in the same month from 2010 to 2012. Yu et al. [16] suggested that the sum of the contributions of all pollutants is the best way to reflect the linear relationship between air pollution and health risks. The same sum was correlated with the costs and number of hospitalizations, which resulted in the curves of the figure. When rainfall decreased, especially in May and September (cold months with the lowest rainfall), there was an increase in pollutant emissions that consequently affected the population's health by increasing the number of hospitalizations for respiratory diseases. Rain is responsible for gas dispersion and consequently improves the air quality. Therefore, November and February showed a decrease in hospitalizations due to respiratory diseases because of a reduction in emissions.

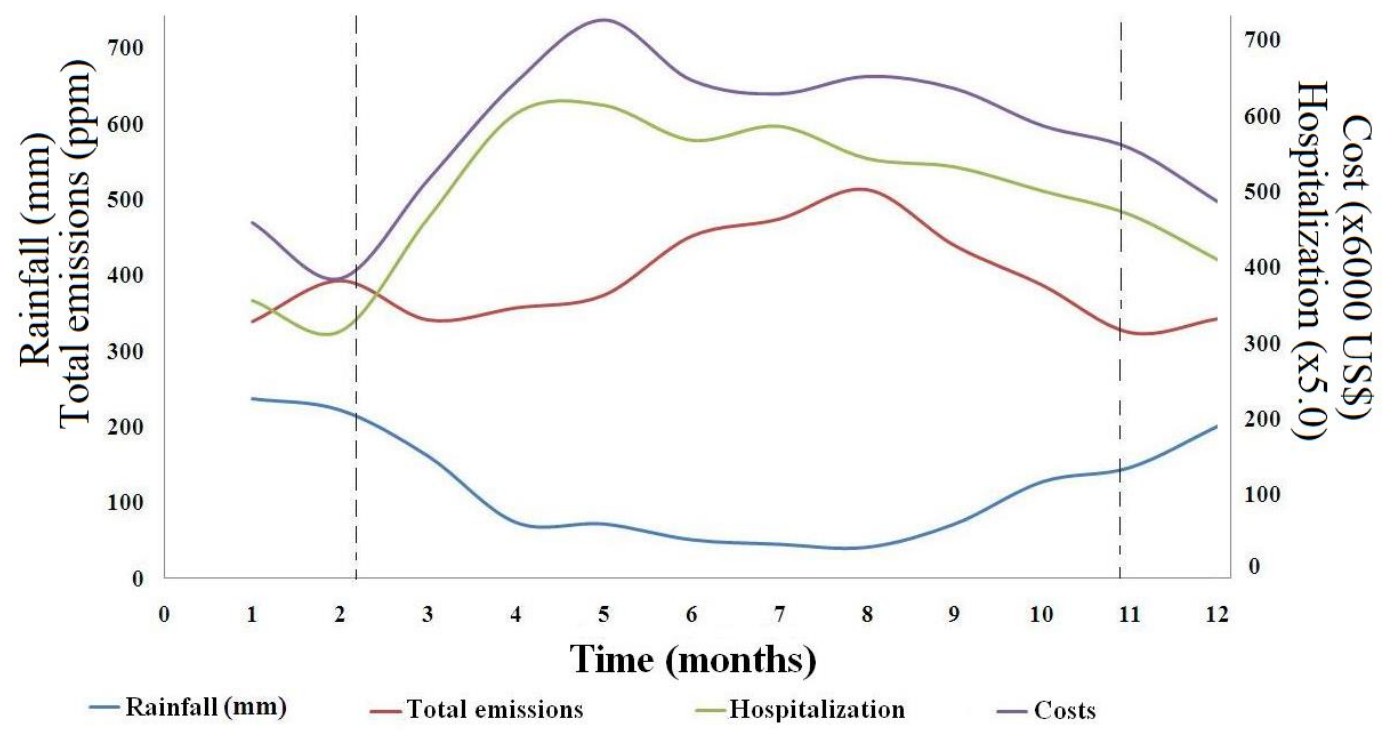

Figure 4. Behavior of the total emissions, costs, number of hospitalizations, and rainfall. 
According to Duhanyan and Roustan [56] and Zhao et al. [57], the decrease in the concentration of most polluting gases is associated with the below-cloud scavenging by precipitation, in which atmospheric particles are eliminated by falling raindrops. Aerosol particles released or formed in the atmosphere can be removed by wet scavenging or dry deposition. Wet scavenging is responsible for cleaning the polluted atmosphere [57]. The process of particulate transport models based on mass continuity equations, which is influenced by raindrop and PM radius, concentration, air temperature and pressure, and the distance of the falling raindrop to the bottom of the cloud [56].

The climate in the city of São Paulo is very rainy between November and March, which facilitates the removal of pollutants by below-cloud scavenging, improving air quality during this period; the opposite effect is observed between May and September, which has a cold and dry climate. Below-cloud scavenging also explains the removal of the other polluting gases mentioned above [56,57].

In the city of São Carlos, Cruz et al. [58] proved a relationship between the increased hospital admissions due to respiratory diseases and climate change for 2008-2012. Natali et al. [59] suggested that the increased number of hospitalization cases in children and adolescents due to pneumonia in São Paulo between summer and autumn was because of pollutant emissions. They also linked seasonal climate changes from a single day to increased susceptibility. Kumar and Goel [60] stated that the lack of rainfall and cold months were mainly related to the onset or worsening of asthma, COPD, and infectious diseases. Cold air can trigger an asthma attack in an individual, and during the winter months there is a clear temperature limit below which mortality increases significantly. The influence of climate and $\mathrm{PM}_{2.5}$ on human mortality has also been proven in recent studies on 22 countries $[57,61,62]$, which corroborates the results of the present study.

\subsection{Effect of Parameters on the Air Quality Index}

Figure 5 presents the air quality indices calculated from the available data during the study period. All calculations were performed with Equation (1). The figure is colored in the same manner as the website of CETESB for easier understanding. The air quality indices show moderate to bad levels compared to the CONAMA-SP standard [36]. $\mathrm{PM}_{2.5}, \mathrm{PM}_{10}$, and $\mathrm{O}_{3}$ had the worst quality levels, so their values were used to represent the quality indices throughout the study period. PM showed the worst level for more than $66 \%$ of the calculated values.

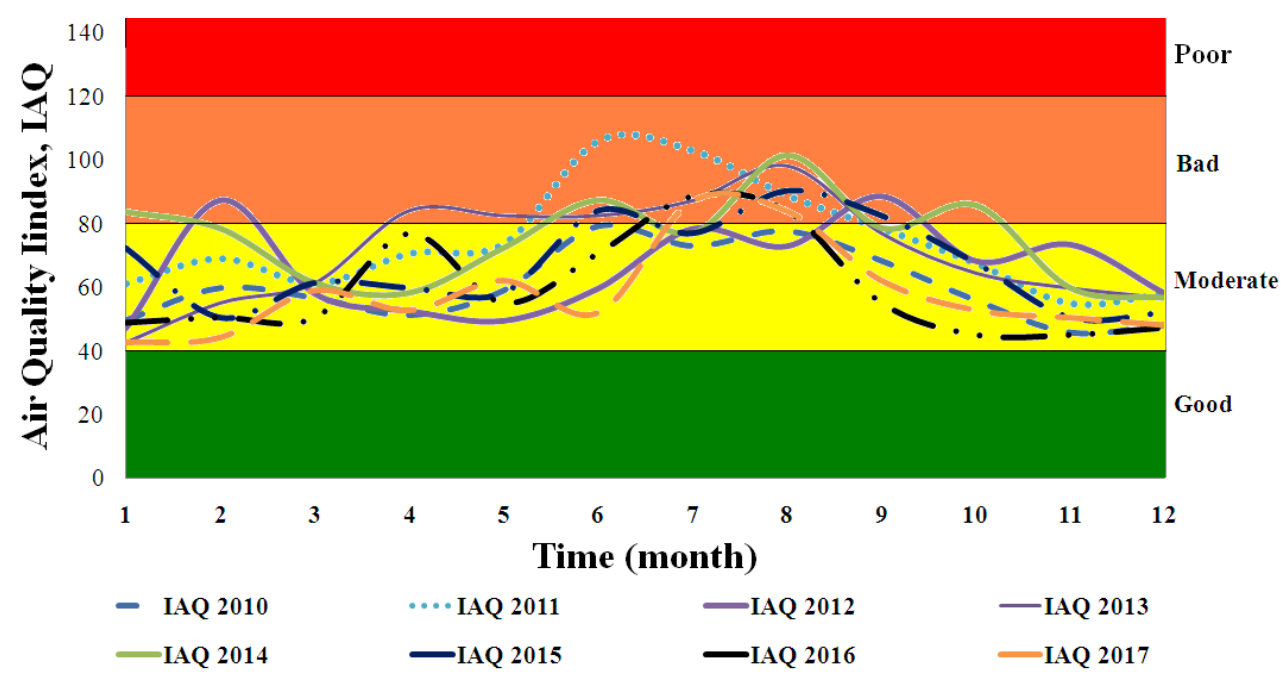

Figure 5. Variation of the air quality indices in the studied period.

The air quality of São Paulo was between moderate and bad throughout the study period. Between June and September, all data indicated poor air quality; these months correspond to the period with the lowest rainfall for this city. With moderate air quality according to CONAMA-SP, sensitive groups of people may experience dry cough and tiredness. With poor quality, normal people may 
experience dry cough, tiredness, and burning eyes, noses, and throat; sensitive people may experience serious health damage.

\subsection{Correlation of Factors with Costs and Hospitalizations for Respiratory Diseases}

Table 6 presents the correlation of pollutant emissions with hospitalization cases. All gaseous pollutants showed a moderate to strong correlation with the hospitalization cases for most years of the study period. For 2012, 2013, 2015, 2016, and 2017, two or more parameters showed moderate or strong correlation with the number of hospitalizations. In 2013, all pollutants showed a strong correlation. This was a year with a water crisis and lack of rainfall, which increased the dry air mass and non-dispersion of pollutants in the atmosphere. Once pollutants became concentrated in the air, overexposure in places with heavy traffic aggravated hospitalization cases for respiratory diseases. The most susceptible patients were the elderly and children. The rainfall index indicated a very strong and inversely proportional correlation with the number of hospitalizations due to respiratory diseases, especially in the colder months of the year.

Table 6. Total item correlation of pollutant emissions with cost and hospitalizations for respiratory diseases.

\begin{tabular}{cccccccccc}
\hline \multirow{2}{*}{ Year } & Correlation with & \multicolumn{7}{c}{ Parameters } \\
\cline { 3 - 9 } & & $\mathbf{M P}_{\mathbf{1 0}}$ & $\mathbf{M P}_{\mathbf{2 . 5}}$ & $\mathbf{O}_{\mathbf{3}}$ & $\mathbf{C O}$ & $\mathbf{N O}_{\mathbf{2}}$ & $\mathbf{S O}_{\mathbf{2}}$ & IAQ & Rainfall \\
\hline \multirow{2}{*}{2010} & Hospitalization & 0.14 & & -0.49 & 0.01 & 0.20 & 0.35 & 0.12 & -0.73 \\
\multirow{2}{*}{2011} & Cost & -0.23 & & 0.03 & -0.53 & -0.23 & 0.02 & -0.23 & -0.35 \\
& Hospitalization & 0.09 & 0.15 & -0.57 & 0.12 & 0.11 & 0.35 & 0.11 & -0.58 \\
\multirow{2}{*}{2012} & Cost & -0.12 & -0.09 & -0.28 & -0.13 & -0.31 & 0.28 & -0.13 & -0.48 \\
\multirow{2}{*}{2013} & Hospitalization & 0.31 & -0.04 & -0.64 & 0.51 & 0.44 & 0.44 & 0.18 & -0.95 \\
& Cost & 0.43 & 0.12 & -0.42 & 0.39 & 0.11 & 0.41 & 0.02 & -0.86 \\
2014 & Hospitalization & 0.60 & 0.83 & -0.43 & 0.68 & 0.62 & 0.74 & 0.78 & -0.88 \\
& Cost & 0.8 & 0.67 & -0.53 & 0.82 & 0.63 & 0.67 & 0.81 & -0.77 \\
2015 & Hospitalization & 0.28 & 0.27 & -0.72 & 0.33 & 0.50 & 0.25 & 0.29 & -0.79 \\
& Cost & 0.32 & 0.39 & -0.69 & 0.58 & 0.18 & 0.21 & 0.22 & -0.78 \\
2016 & Hospitalization & 0.11 & 0.40 & -0.76 & 0.46 & 0.39 & 0.38 & 0.41 & -0.85 \\
& Cost & 0.62 & 0.52 & -0.60 & 0.52 & 0.20 & 0.60 & 0.52 & -0.75 \\
2017 & Hospitalization & 0.54 & 0.68 & -0.81 & 0.50 & 0.60 & 0.61 & 0.67 & -0.88 \\
& Cost & 0.53 & 0.72 & -0.23 & 0.54 & 0.69 & 0.73 & 0.71 & -0.90 \\
& Hospitalization & 0.57 & 0.53 & -0.30 & 0.24 & 0.41 & 0.32 & 0.53 & -0.83 \\
& Cost & 0.78 & 0.63 & -0.53 & 0.41 & 0.28 & 0.14 & 0.69 & -0.78 \\
\hline
\end{tabular}

Compared with previous results, the parameters with the strongest influence on hospitalizations due to respiratory diseases were $\mathrm{PM}_{10}, \mathrm{PM}_{2.5}$, and $\mathrm{O}_{3}$ because they were above WHO standards throughout the study period and made up the $I_{\mathrm{AQ}}$ values, which also had a medium to strong correlation in the worst years. Arbex et al. [3] observed that these pollutants are the major causes of respiratory allergic diseases, including symptoms such as coughing, upper airway irritation, and COPD.

The correlations above present evidence but do not confirm a relationship between $\mathrm{CO}, \mathrm{NO}_{2}$, and $\mathrm{SO}_{2}$ emissions and cases of hospitalizations for respiratory diseases. According to $\mathrm{Yu}$ et al. [16], the influence of any pollutant cannot be ruled out because the total human health risk for exposure to several pollutants is the sum of the risks associated with each air pollutant.

Figure 4 indicates that the costs, emissions, and hospitalizations show parabolic behavior over time. Rainfall shows the same but inversely. Thus, rainfall likely influences the reduction in hospitalizations in rainy periods. Thus, the use of the partial item correlation presented in Table 7 within the period of lower rainfall should improve the adjustment and prove the validity of the assumptions in this study. For this purpose, data from the beginning of the rainless period (May) to the end of the year (December) were used in the analysis, as during this period there was an increase in hospitalizations. And so, the influence of polluting gases and the air quality index on costs and hospitalizations for 
respiratory diseases was confirmed since the absolute majority of the correlations were between moderate and strong.

Table 7. Partial correlation of pollutant emissions with cost and hospitalizations for respiratory diseases.

\begin{tabular}{|c|c|c|c|c|c|c|c|c|}
\hline \multirow{2}{*}{ Year } & \multirow{2}{*}{ Correlation with } & \multicolumn{7}{|c|}{ Parameters } \\
\hline & & $\mathrm{MP}_{10}$ & $\mathrm{MP}_{2.5}$ & $\mathrm{O}_{3}$ & $\mathrm{CO}$ & $\mathrm{NO}_{2}$ & $\mathrm{SO}_{2}$ & IAQ \\
\hline \multirow[b]{2}{*}{2010} & Hospitalization & 0.25 & - & 0.69 & 0.05 & 0.40 & 0.54 & 0.28 \\
\hline & Cost & 0.98 & - & 0.28 & -0.83 & -0.53 & -0.72 & -0.91 \\
\hline \multirow{2}{*}{2011} & Hospitalization & 0.86 & 0.69 & 0.48 & 0.51 & 0.65 & 0.61 & 0.73 \\
\hline & Cost & 0.83 & -0.78 & 0.51 & 0.52 & -0.09 & 0.31 & -0.22 \\
\hline \multirow{2}{*}{2012} & Hospitalization & 0.60 & 0.23 & -0.64 & 0.82 & 0.58 & 0.85 & 0.72 \\
\hline & Cost & 0.74 & -0.22 & -0.12 & -0.10 & 0.27 & 0.63 & 0.31 \\
\hline \multirow{2}{*}{2013} & Hospitalization & 0.77 & 0.83 & 0.28 & 0.92 & 0.81 & 0.73 & 0.92 \\
\hline & Cost & 0.96 & 0.73 & -0.31 & 0.40 & 0.92 & 0.78 & 0.96 \\
\hline \multirow{2}{*}{2014} & Hospitalization & 0.47 & 0.62 & 0.40 & 0.53 & 0.57 & 0.81 & 0.59 \\
\hline & Cost & 0.97 & 0.61 & -0.58 & 0.4 & 0.41 & 0.11 & 0.62 \\
\hline \multirow{2}{*}{2015} & Hospitalization & 0.62 & 0.75 & 0.70 & 0.92 & 0.66 & 0.61 & 0.73 \\
\hline & Cost & 0.86 & 0.52 & -0.32 & 0.8 & 0.83 & 0.83 & 0.93 \\
\hline \multirow{2}{*}{2016} & Hospitalization & 0.70 & 0.93 & -0.81 & 0.85 & 0.93 & 0.94 & 0.91 \\
\hline & Cost & 0.67 & 0.53 & -0.78 & 0.34 & 0.91 & 0.97 & 0.96 \\
\hline \multirow{2}{*}{2017} & Hospitalization & 0.58 & 0.74 & -0.70 & 0.90 & 0.58 & 0.19 & 0.81 \\
\hline & Cost & 0.72 & 0.92 & -0.89 & 0.58 & 0.61 & -0.31 & 0.73 \\
\hline
\end{tabular}

The only parameter that showed a moderate to strong correlation was the rainfall index. However, because the correlation was negative, this indicates that a higher rainfall index meant fewer people were hospitalized for respiratory diseases. Because this parameter had an inverse influence on the number of hospitalized people, the partial item correlation was proposed. The less rainy period was chosen to test the hypothesis, and the correlation from May to December was considered. Thus, the influence of each pollutant in the air of São Paulo on hospitalizations for respiratory diseases could be determined. Machin and Nascimento [4] also observed that there is a greater correlation between pollutant gas emissions and hospitalizations for respiratory diseases from June to December, in the Midwest Region of Brazil.

Early in the study period, no correlation was observed between costs and gas emissions in São Paulo (only $\mathrm{MP}_{10}$ ). However, from 2013 the correlation increased for most parameters and was strong almost every year for $\mathrm{PM}_{10}$. Thus, the emissions also showed a clear correlation with the increase in hospitalization costs for respiratory diseases in São Paulo. Gao et al. [7] realized that GHG mitigation strategies can bring about substantial and possibly cost-effective public health co-benefits. These are highly relevant to policymakers and other stakeholders because they demonstrate the compounding value of taking concerted action against climate change and air pollution.

All pollutants showed a moderate to strong correlation in several consecutive years, which indicates that they are potentially direct causes or influences on the development of respiratory diseases and the increasing number of hospitalizations. In 2010, 2011, and 2015, $\mathrm{O}_{3}$ showed a moderate to strong correlation with high values at the beginning and end of the years, as shown in Figure 3. However, these values were influenced by rainfall, so correlating $\mathrm{O}_{3}$ with hospitalizations was difficult. Thus, this research could not confirm that this parameter influenced hospitalizations due to respiratory diseases. Thus, PM was concluded to be the dominant factor influencing the costs and number of hospitalizations for respiratory diseases.

Yanagi et al. [63] found that cancer incidence in the skin, lungs, thyroid, larynx, and bladder presented correlation coefficients of $0.60-0.80$ with exposure to $\mathrm{PM}_{10}$ for some months of the year. In a similar study for São Paulo, Gouveia et al. [25] associated inhalable PM with increases of 4.6\% in hospitalizations for asthma in children and $4.3 \%$ in chronic obstructive pulmonary disease in the elderly. Nascimento and Francisco [34] found that an increase of $10 \mu \mathrm{g} / \mathrm{m}^{3}$ of PM increased the risk of 
hospitalizations by $13 \%$ in the municipality of São José dos Campos. Similarly, Cesar et al. [64] showed that an increase in $\mathrm{PM}_{2.5}$ emissions increased the number of hospitalizations for respiratory diseases in children from $7.9 \%$ to $8.6 \%$ in the less rainy months for the city of Piracicaba. In São José dos Campos, Amancio and Nascimento [33] estimated the risk of hospitalization for asthma in children to increase by $19 \%$ after intense exposure to $\mathrm{SO}_{2}$ for $3 \mathrm{~h}$. The low rainfall ratios in some months of the year favorably contribute to the non-dispersion of gases and pollutants in the atmosphere. This increased the pollutant concentration, which exposed even more susceptible patients such as the elderly and children to risk.

Vormittag et al. [65] pointed out that these problems can be solved by using biodiesel to improve air quality, which will have benefits in the area of health. In a life cycle analysis of biodiesel production from used frying oil, Chua et al. [66] demonstrated that the emission of all gas components $\left(\mathrm{SO}_{2}, \mathrm{CO}\right.$, $\mathrm{NO}_{2}, \mathrm{PM}_{2.5}$, and $\mathrm{PM}_{10}$ ) was reduced by $90 \%$. They noted that, in a similar survey conducted in the USA for biodiesel made from soybean oil (i.e., edible oil), the reduction in the emitted gas components was $80 \%$. This demonstrates one more advantage of using frying oil instead of edible oil for biodiesel because the former contributes significantly more to reducing emissions and global warming [67]. They showed that, compared to diesel, biodiesel obtained from waste oils provides a shorter ignition delay and reduced heat release rate as well as slightly higher efficiency. While a small amount of fuel is sacrificed, the hydrocarbon (HC), CO, and PM emissions are reduced. Miranda et al. [2] also proved that pollutant emissions were reduced and that the power of the generator did not change when biodiesel was used in place of diesel oil. Thus, switching from diesel to the renewable and less polluting biodiesel does not influence engine ignition and is an environmentally sound approach to replacing fossil fuels.

Brazil has had cars running on alcohol for over 50 years. However, the adoption of biodiesel has been slow and gradual. Because of pressure from the oil sector, since it first became available in 2005 to the present, only $10 \%$ biodiesel is blended with diesel oil in automobiles with cyclodiesel engines in Brazil. Critics should be reminded that Rudolf Diesel himself, the inventor of cyclodiesel engines, attested to the successful use of peanut oil as a fuel at the 1900 Paris World Exposition. Thus, there is no justification for not fully exchanging diesel oil for biodiesel $[1,2]$.

Brazil will continue to feel the ill effects of using diesel oil on human health, and its costs associated with hospitalization for respiratory diseases. As long as politicians and managers do not understand the link between fuel use and human health, money will continue to be spent on healthcare $[7,68]$ when it should be invested in other sectors or improving public health infrastructure.

The adoption of policies for the increase of green infrastructures in cities is another option, for according to Abhijith et al. [69] and Janhäll [70], these areas are responsible for reducing air pollution in urban zones. They advocate the adoption of green infrastructures such as green walls and roofs on buildings, and tree planting and tall vegetation on streets and roads to improve air quality in cities.

This work shows that the cost on human health is significant due to emissions of gaseous pollutants. Brazil should implement stricter policies to improve the air quality of its major cities and develop a viable alternative to replace diesel vehicles. The substitution of fossil fuels for renewable sources is an alternative [1,2], and investment policies in green urban infrastructure should be adopted to minimize the effects of gaseous pollutants on human health in the city of São Paulo $[69,70]$.

\section{Conclusions}

Gas emissions and hospitalizations for respiratory diseases behaved inversely to monthly rainfall in São Paulo. This indicates that in dry months with no precipitation the pollutant concentrations in the atmosphere tend to increase, which leads to a rise in the number of hospitalizations for respiratory diseases. The air quality indices indicated moderate to bad levels throughout the study period. In particular, the air quality was poor between June and September, which coincides with the non-rainy period of São Paulo. Of all pollutants considered in this study, $\mathrm{PM}_{10}, \mathrm{PM}_{2.5}$, and $\mathrm{O}_{3}$ were observed to 
be most beyond the Brazilian and international standards. Both types of PM presented values close to or well above the limits, and their Pearson correlations indicated a correlation with the increased hospitalization cases for diseases caused by the respiratory system, especially in 2013 and 2016. $\mathrm{PM}_{10}$ was always above $50 \mu \mathrm{g} / \mathrm{m}^{3}$ for all months of the study period and exceeded $100 \mu \mathrm{g} / \mathrm{m}^{3}$ in low rainfall months, which led to poor air quality. $\mathrm{PM}_{2.5}$ exceeded $20 \mu \mathrm{g} / \mathrm{m}^{3}$ every year and is currently twice as high as WHO standards. $\mathrm{O}_{3}$ maintained a moderate level $\left(100 \mu \mathrm{g} / \mathrm{m}^{3}\right)$ according to the CONAMA-SP and WHO standards but exceeded them later in the study period; the average level increased at the end of the year, and a positive correlation was observed with hospitalizations for respiratory diseases. In most of the years considered in this study, a medium to strong correlation was observed between hospitalization costs and most parameters. The correlation was strong almost every year for $\mathrm{PM}_{10}$. Thus, emissions also correlate with the increased hospitalization costs for respiratory diseases in São Paulo. The costs and hospitalizations increased during the study period, reaching 302,000 hospitalizations at an average cost of 368 USD, for a total cost of 111 million USD. Brazil should implement stricter policies to improve the air quality of its major cities and develop a viable alternative to replace diesel vehicles.

Author Contributions: Conceptualization, J.C.C.S.; A.C.M.; S.C.d.S.F. and L.L.H.; Methodology, A.C.M.; L.L.H. and J.C.C.S.; Formal Analysis, C.L.K.Y.; T.M.B. and J.C.C.S.; Resources, S.C.d.S.F.; A.C.M.; C.L.K.Y.; F.T.B. and J.C.C.S.; Writing-Original Draft Preparation, F.T.B.; J.C.C.S. and L.L.H.; Writing-Review \& Editing; C.L.K.Y.; F.T.B., E.B.T. and J.C.C.S.; Supervision, L.L.H.; F.T.B.; E.B.T. and J.C.C.S.; Project Administration, E.B.T.; F.T.B. and J.C.C.S. All authors have read and agreed to the published version of the manuscript.

Funding: This research received no external funding.

Acknowledgments: The authors thank the University of São Paulo (USP) and the Fundação Carlos Vanzolini (FCAV) for financial support. This study was financed in part by the Coordenação de Aperfeiçoamento de Pessoal de Nível Superior-Brasil (CAPES)-Finance Code 001 and National Council for Scientific and Technological Development (CNPq), Brasilia, Brazil, Financial Code:305987/2018-6.

Conflicts of Interest: The authors declare no conflicts of interest.

\section{References}

1. Benvenga, M.A.C.; Librantz, A.F.H.; Santana, J.C.C.; Tambourgi, E.B. Genetic algorithm applied to study of the economic viability of alcohol production from Cassava root from 2002 to 2013. J. Clean. Prod. 2016, 113, 483-494. [CrossRef]

2. Miranda, A.C.; Silva Filho, S.C.; Tambourgi, E.B.; Santana, J.C.C.; Vanalle, R.M.; Gherhardt, F. Analysis of the costs and logistics of biodiesel production from used cooking oil in the metropolitan region of Campinas (Brazil). Renew. Sustain. Energy Rev. 2018, 88, 373-379. [CrossRef]

3. Arbex, M.A.; Santos, U.P.; Martins, L.C.; Saldiva, P.H.N.; Pereira, L.A.A.; Braga, A.L.F. Air pollution and the respiratory system. J. Bras. Pneumol. 2012, 38, 643-655. [CrossRef] [PubMed]

4. Machin, A.B.; Nascimento, L.F.C. Efeitos da exposição a poluentes do ar na saúde das crianças de Cuiabá, Mato Grosso, Brasil. Cad. de Saúde Pública 2018, 34. [CrossRef] [PubMed]

5. SUS, Brazilian Health System, Sistema Único De Saúde. Data SUS. Available online: http://portalms.saude. gov.br/sistema-unico-de-saude (accessed on 12 February 2018).

6. Ravina, M.; Panepinto, D.; Zanetti, M.C. DIDEM-An integrated model for comparative health damage costs calculation of air pollution. Atmos. Environ. 2018, 173, 81-95. [CrossRef]

7. Gao, J.; Kovats, S.; Vardoulakis, S.; Wilkinson, P.; Woodward, A.; Li, J.; Gu, S.; Liu, X.; Wu, H.; Wang, J.; et al. Public health co-benefits of greenhouse gas emissions reduction: A systematic review. Sci. Total Environ. 2018, 627, 388-402. [CrossRef]

8. Kunzli, N.; Perez, L.; Rapp, R. Air quality and health. Eur. Respir. Soc. 2014, 44, 614-626.

9. Gehring, U.; Wijga, A.H.; Brauer, M.; Fischer, P.; Jongste, J.C.; Kerkhof, M.; Oldenwening, M.; Smit, H.A.; Brunekreef, B. Traffic-related air pollution and the development of asthma and allergies during the first 8 years of life. Am. J. Respir. Crit. Care Med. 2010, 181, 596-603. [CrossRef] [PubMed] 
10. De Marco, A.; Proietti, C.; Anav, A.; Ciancarella, C.; D’Elia, I.; Fares, S.; Fornasier, M.F.; Fusaro, L.; Gualtieri, M.; Manes, F.; et al. Impacts of air pollution on human and ecosystem health, and implications for the National Emission Ceilings Directive: Insights from Italy. Environ. Int. 2019, 125, 320-333. [CrossRef] [PubMed]

11. Ko, F.W.; Tam, W.; Wong, T.W.; Chan, D.P.; Tung, A.H.; Lai, C.K.; Hui, D.S. Temporal relationship between air pollutants and hospital admissions for chronic obstructive pulmonary disease in Hong Kong. Thorac. Soc. 2007, 62, 780-785. [CrossRef]

12. Andersen, Z.J.; Hvidberg, M.; Jensen, S.S.; Ketzel, M.; Loft, S.; Sørensen, M.; Tjønneland, A.; Overvad, K.; Raaschou-Nielsen, O. Chronic obstructive pulmonary disease and long-term exposure to traffic-related air pollution: A cohort study. Am. J. of Respir. Crit. Med. 2011, 183, 455-461. [CrossRef] [PubMed]

13. Hu, G.; Zhou, Y.; Tian, J.; Yao, W.; Li, J.; Li, B.; Ran, P. Risk of COPD from exposure to biomass smoke: A metaanalysis. Chem. Rev. 2010, 138, 20-31.

14. Reis, H.; Reis, C.; Sharip, A.; Reis, W.; Zhao, Y.; Sinclair, R.; Beeson, L. Diesel exhaust exposure, its multi-system effects, and the effect of new technology diesel exhaust. Environ. Int. 2018, 14, 252-265. [CrossRef]

15. Santos, V.P.; Medeiros, A.P.P.; De Lima, T.A.C. O papel dos poluentes atmosféricos sobre o peso ao nascer em cidade de médio porte Paulista. Rev. Paul. Pediatr. 2014, 32, 306-312.

16. Yu, T.; Wang, W.; Ciren, P.; Zhu, Y. Assessment of human health impact from exposure to multiple air pollutants in China based on satellite observations. Int. J. Appl. Earth Obs. Geoinf. 2016, 52, 542-553. [CrossRef]

17. WHO, World Health Organization. Air Quality Guidelines; Global Update 2005. Particulate Matter, Ozone, Nitrogen Dioxide and Sulfur Dioxide; World Health Organization: Copenhagen, Denmark, 2005; Available online: http://www.euro.who.int/en/health-topics/environment-and-health/air-quality/publications/ pre2009/air-quality-guidelines.-global-update-2005.-particulate-matter,-ozone,-nitrogen-dioxide-andsulfur-dioxide (accessed on 2 July 2019).

18. Andrade, M.F.; Kumar, P.; Freitas, E.D.; Ynoue, R.Y.; Martins, J.; Nogueira, T.; Martinez, P.P.; Miranda, R.M.; Albuquerque, T.; Gonçalvez, F.L.T.; et al. Air quality in the megacity of São Paulo: Evolution over the last 30 years and future perspectives. Atmos. Environ. 2017, 159, 66. [CrossRef]

19. Bravo, M.A.; Son, J.; De Freitas, C.U.; Gouveia, N.; Bell, M.L. Air pollution and mortality in São Paulo, Brazil: Effects of multiple pollutants and analysis of susceptible populations. J. Expo. Sci. Environ. Epidemiol. 2016, 26, 150-161. [CrossRef] [PubMed]

20. Miranda, R.M.; Lopes, F.; Rosario, N.E.; Yamasoe, M.A.; Landulfo, E.; Andrade, M.F. The relationship between aerosol particles chemical composition and optical properties to identify the biomass burning contribution to fine particles concentration: A case study for Sao Paulo city, Brazil. Environ. Monit. Assess. 2017, 189, 9-15. [CrossRef] [PubMed]

21. Cintra, M. Os Custos dos Congestionamentos na Cidade de São Paulo; FGV Digital Home Page. Available online: https://bibliotecadigital.fgv.br/dspace/handle/10438/11576 (accessed on 9 June 2020).

22. Fajersztajn, L.; Veras, M.; Saldiva, P.H.N. Como as cidades podem favorecer ou dificultar a promoção da saúde de seus moradores? Estud. Avançados 2016, 30, 7-27. [CrossRef]

23. Costa, R.G.R.; Silva, C.G.T.; Cohen, S.C. A origem do caos-A crise de mobilidade no Rio de Janeiro e a ameaça à saúde urbana. Cad. Metropóle 2013, 15, 411-431. [CrossRef]

24. Pinheiro, S.L.L.A.; Saldiva, P.H.N.; Schwartz, J.; Zanobetti, A. Isolated and synergistic effects of PM10 and average temperature on cardiovascular and respiratory mortality. Rev. Saúde Pública 2014, 12, 756-765. [CrossRef]

25. Gouveia, N.; Corallo, F.P.; Leon, A.C.P.; Junger, W.; Freitas, C.U. Air pollution and hospitalizations in the largest Brazilian metropolis. Rev. Saude Pública 2017, 51. [CrossRef]

26. Bernardes, J.; Tráfego Intenso em São Paulo Aumenta Internação por Doença Respiratória. Agencia USP de Notícias, 14 de Maio de 2013. Available online: http://www5.usp.br/26980/trafego-intenso-em-sao-pauloaumenta-internacao-por-doenca-respiratoria/ (accessed on 5 May 2018).

27. DENATRAN, National Traffic Department. Available online: https://portalservicos.denatran.serpro.gov.br/\#/ (accessed on 5 December 2018).

28. ANP, National Agency of Petroleum, Natural Gas and Biofuels of Brazil. Available online: www.anp.gov.br (accessed on 28 April 2019). 
29. Vilas Boas, D.S.; Matsuda, M.; Toffoletto, O.; Garcia, M.L.B.; Saldiva, P.H.N.; Marquezini, M.V. Workers of São Paulo city, Brazil, exposed to air pollution: Assessment of genotoxicity. Mutat. Res. Genet. Toxicol. Environ. Mutagenesis 2018, 834, 18-24. [CrossRef] [PubMed]

30. De Oliveira, A.A.F.; De Oliveira, T.F.; Dias, M.F.; Medeiros, M.H.G.; Di Mascio, P.; Veras, M.; Lemos, M.; Marcourakis, T.; Saldiva, P.H.N.; Loureiro, A.P.M. Genotoxic and epigenotoxic effects in mice exposed to concentrated ambient fine particulate matter (PM2.5) from São Paulo city, Brazil. Part. Fibre Toxicol. 2018, 15, 1-12. [CrossRef] [PubMed]

31. Saldiva, S.; Barrozo, L.C.; Failla, M.; Bonilha, E.; Bernal, R.; Oliveira, R.; Saldiva, P.H.N. Small-Scale Variations in Urban Air Pollution Levels Are Significantly Associated with Premature Births: A Case Study in São Paulo, Brazil. Int. J. Environ. Res. Public Health 2018, 15, 2236. [CrossRef] [PubMed]

32. Missagia, S.; Amaral, C.A.S.; Jesus, A.S.; Arbex, M.A.; Santos, U.P.; André, C.D.S.; André, P.A.; Saldiva, P.H.N.; Martins, L.C.; Braga, A.L.F.; et al. Evaluation of peak expiratory flow in adolescents and its association with inhalable particulate in a Brazilian medium-sized city. Rev. Bras. Epidemiol. 2018, 21, 1-12. [CrossRef]

33. Amâncio, T.C.; Nascimento, C.F.L. Poluição ambiental e óbitos devido a acidente vasculoencefálico em uma cidade com baixos níveis de poluentes: Estudo ecológico de séries temporais. São Paulo Med. J. 2014, 132, 353-358.

34. Nascimento, L.F.C.; Francisco, J.B. Particulate matter and hospital admission due to arterial hypertension in a medium-sized Brazilian city. Cad. Saúde Pública 2013, 29, 1565-1571. [CrossRef] [PubMed]

35. Paiva, R.F.P.S. Hospital morbidity due to diseases associated with air pollution in the city of Volta Redonda, Rio de Janeiro: Cases and economic cost. Cad. Saúde Coletiva 2014, 22, 127-133. [CrossRef]

36. CETESB, Environmental Sanitation Technology Company. Available online: http://www.cetesb.gov.br (accessed on 5 December 2019).

37. Berssaneti, F.T.; Saut, A.M.; Barakat, M.F.; Calarge, F.A. Is there any link between accreditation programs and the models of organizational excellence? Rev. Esc. Enferm. 2016, 50, 648-655. [CrossRef]

38. Erickson, A.C.; Brauer, M.; Christidis, T.; Pinault, L.; Crouse, D.L.; Donkelaar, A.; Weichenthal, S.; Pappin, A.; Tiepkema, M.; Martin, R.V.; et al. Evaluation of a method to indirectly adjust for unmeasured covariates in the association between fine particulate matter and mortality. Environ. Res. 2019, 175, 108-116. [CrossRef] [PubMed]

39. Santos, U.P.; Braga, A.L.F.; Garcia, M.L.B.; Pereira, L.A.A.; Lin, C.A.; Chiarelli, P.A.; de André, C.A.S.; de André, P.A.; Singer, J.M.; Saldiva, P.H.N. Exposure to fine particles increases blood pressure of hypertensive outdoor workers: A panel study. Environ. Res. 2019, 174, 88-94. [CrossRef] [PubMed]

40. Saut, A.M.; Berssaneti, F.T.; Moreno, M.C. Evaluating the impact of accreditation on Brazilian healthcare organizations: A quantitative study. Int. J. Qual. Health Care 2017, 29, 713-721. [CrossRef]

41. Xia, B.; Zhou, Y.; QingyangZhu, O.; Zhao, Y.; Wang, Y.; Ge, W.; Yang, Q.; Zhao, Y.; Wang, P.; Si, J.; et al. Personal exposure to $\mathrm{PM}_{2.5}$ constituents associated with gestational blood pressure and endothelial dysfunction. Environ. Pollut. 2019, 250, 346-356. [CrossRef] [PubMed]

42. Berssaneti, F.T.; Berger, S.; Saut, A.M.; Vanalle, R.M.; Santana, J.C.C. Value generation of remanufactured products: Multi-case study of third-party companies. Sustainability 2019, 11, 584. [CrossRef]

43. Pereira, E.; Poluentes No Ar de SP Superam Níveis Recomendados Pela OMS. Folha de São Paulo, 1 June 2014. Available online: http://www1.folha.uol.com.br/saopaulo/2014/06/1462595-poluentes-no-ar-de-sp-superamniveis-recomendados-pela-oms.shtml (accessed on 5 May 2018).

44. Mascarenhas, M.D.M.; Vieira, L.C.; Lanzieri, T.M.; Leal, A.P.P.R.; Duarte, A.F.; Hatch, D.L. Poluição atmosférica devida à queima de biomassa florestal e atendimentos de emergência por doença respiratória em Rio Branco, Brasil-Setembro, 2005. J. Bras. Pneumol. 2008, 34, 42-46. [CrossRef]

45. Pandya, R.J.; Solomon, G.; Kinner, A.; Balmes, J.R. Diesel exhaust and asthma: Hypotheses and molecular mechanism of action. Environ. Health Perspect. 2002, 110 (Suppl. 1), 103-112. [CrossRef]

46. Polezer, G.; Tadano, Y.; Siqueira, H.V.; Godoi, A.F.L.; Yamamoto, C.I.; De André, P.A.; Pauliquevis, T.; Andrade, M.F.; Oliveira, A.; Saldiva, P.H.N.; et al. Assessing the impact of PM 2.5 on respiratory disease using artificial neural networks. Environ. Pollut. 2018, 235, 394-403. [CrossRef]

47. Negrisoli, J.; Nascimento, C.F.L. Poluentes atmosféricos e internações por pneumonia em crianças. Rev. Paul. Pediatr. 2013, 31, 501-506. [CrossRef]

48. Barbosa, S.M.M.; Farhat, S.C.L.; Martins, L.C.; Pereira, L.A.A.; Saldiva, P.H.N.; Zanotti, A.; Braga, A.L. Air pollution and children's health: Sickle cell disease. Cad. Saúde Pública 2015, 31, 265-275. [CrossRef] 
49. IBGE, Brazilian Institute of Geography and Statistic. Panorama over the city of São Paulo. Available online: https://cidades.ibge.gov.br/brasil/sp/sao-paulo/panorama (accessed on 7 November 2019).

50. Pacheco, M.T.; Parmigiani, M.M.M.; Amdrade, M.F.; Morawska, L.; Kumar, P. A review of emissions and concentrations of particulate matter in the three major metropolitan areas of Brazil. J. Transp. Health 2017, 4, 53-72. [CrossRef]

51. Vieira, S.E.; Stein, R.T.; Ferraro, A.A.; Pastro, L.D.; Pedro, S.S.C.; Lemos, M.; Silva, E.R.; Sly, P.D.; Saldiva, P.H. Urban air pollutants are significant risk factors for asthma and pneumonia in children: The influence of location on the measurement of pollutants. Arch. Bronconeumol. 2012, 48, 389-395. [CrossRef] [PubMed]

52. Xiaolin, L.; Yuanxun, Z.; Mingguang, T.; Jiangfeng, L.; Liangman, B.; Guilin, Z.; Yan, L.; Atsuo, I. Atmospheric lead pollution in fine particulate matter in Shanghai, China. J. Environ. Sci. 2009, 21, 1118-1124.

53. Langaro, A.P.; Souza, E. Influence of solar radiation and air humidity on ozone concentration. Rev. Ciências Exatas Terra UNIGRAN 2012, 1, 32-40.

54. Nardocci, A.C.; de Freitas, C.U.; de Leon, A.C.M.P.; Junger, W.L.; Gouveia, N.C. Air pollution and respiratory and cardiovascular diseases: A time series study in Cubatão, São Paulo State, Brazil. Cad. Saúde Pública 2013, 29, 1867-1876. [CrossRef] [PubMed]

55. Jasinski, R.; Pereira, L.A.A.; Braga, A.L.F. Poluição atmosférica e internações hospitalares por doenças respiratórias em crianças e adolescentes em Cubatão, São Paulo, Brasil, entre 1997 e 2004. Cad. Saúde Pública 2011, 27, 2242-2252. [CrossRef]

56. Duhanyan, N.; Roustan, Y. Below-cloud scavenging by rain of atmospheric gases and particulates. Atmos. Environ. 2011, 45, 7201-7217. [CrossRef]

57. Zhao, Q.; Li, S.; Coelho, M.S.Z.S.; Saldiva, P.H.N.; Hu, K.; Abramson, M.J.; Huxley, R.R.; Guo, Y. Assessment of Intraseasonal variation in hospitalization associated with heat exposure in Brazil. JAMA Netw. Open 2019, 2, e187901. [CrossRef]

58. Cruz, D.M.; Ohara, D.G.; Castro, S.S.; Jamami, M. Hospitalization, deaths, expenses respiratory diseases and its relationship with climate change in the municipality of San Carlos-SP, Brazil. Rev. Med. Riberião Preto 2016, 49, 248-257. [CrossRef]

59. Natali, R.M.T.; Santos, D.D.P.S.; Fonseca, A.M.C.; Filomeno, G.C.M.; Figueiredo, A.H.A.; Terrivel, P.M.; Massoni, K.M.; Braga, A.L.F. Perfil de internações hospitalares por doenças respiratórias em crianças e adolescentes da cidade de São Paulo, 2000-2004. Rev. Paul. Pediatr. 2011, 29, 584-590. [CrossRef]

60. Kumar, P.; Goel, A. Concentration dynamics of coarse and fine particulate matter at and around the signalised traffic intersections. Environ. Sci. Process. Impacts 2016, 18, 1220-1235. [CrossRef] [PubMed]

61. Locosselli, G.M.; Camargo, E.P.; Moreira, T.C.L.; EnzoTodesco, E.; Andrade, M.F.; de André, C.D.S.; de André, P.A.; Singer, J.M.; Ferreira, L.S.; Saldiva, P.N.H.; et al. The role of air pollution and climate on the growth of urban trees. Sci. Total Environ. 2019, 666, 652-661. [CrossRef] [PubMed]

62. Sera, F.; Ben Armstrong, A.T.; Vicedo-Cabrera, A.M.; Åström, C.; Bell, M.L.; Chen, B.Y.; Coelho, M.S.Z.S.; Correa, P.M.; Cruz, J.C.; Dang, T.N.; et al. How urban characteristics affect vulnerability to heat and cold: A multi-country analysis. Int. J. Epidemiol. 2019, 48, 1101-1112. [CrossRef]

63. Yanagi, Y.; Assunção, V.J.; Barrozo, V.L. The impact of atmospheric particulate matter on cancer incidence and mortality in the city of São Paulo, Brazil. Cad. Saúde Pública 2012, 28, 1737-1748. [CrossRef] [PubMed]

64. Cesar, G.C.A.; Nascimento, C.F.L.; Carvalho, A.J. Association between exposure to particulate matter and hospital admissions for respiratory disease in children. Rev. Saúde Pública 2013, 47, 1209-1212. [CrossRef]

65. Vormittag, E.M.P.A.; Rodrigues, C.G.; de André, P.A.; Saldiva, P.H.N. Assessment and Valuation of Public Health Impacts from Gradual Biodiesel Implementation in the Transport Energy Matrix in Brazil. Aerosol Air Qual. Res. 2018, 18, 2375-2382. [CrossRef]

66. Chua, C.B.H.; Lee, H.M.; Low, J.S.C. Life cycle emissions and energy study of biodiesel derived from waste cooking oil and diesel in Singapore. Int. J. Life Cycle Assess. 2010, 15, 417-423. [CrossRef]

67. Hasan, M.M.; Rahman, M.M. Performance and emission characteristics of biodiesel-diesel blend and environmental and economic impacts of biodiesel production: A review. Renew. Sustain. Energy Rev. 2017, 74, 938-948. [CrossRef]

68. Naylor, R.L.; Higgins, M.M. The political economy of biodiesel in an era of low oil prices. Renew. Sustain. Energy Rev. 2017, 77, 695-705. [CrossRef] 
69. Abhijith, K.V.; Kumar, P.; Gallagher, J.; McNabola, A.; Baldauf, R.; Pilla, F.; Broderick, B.; Di Sabatino, S.; Pulvirenti, B. Air pollution abatement performances of green infrastructure in open road and built-up street canyon environments-A review. Atmos. Environ. 2017, 162, 71-86. [CrossRef]

70. Janhäll, S. Review on urban vegetation and particle air pollution-Deposition and dispersion. Atmos. Environ. 2015, 105, 130-137. [CrossRef]

(C) 2020 by the authors. Licensee MDPI, Basel, Switzerland. This article is an open access article distributed under the terms and conditions of the Creative Commons Attribution (CC BY) license (http://creativecommons.org/licenses/by/4.0/). 